\title{
APPLICATION OF MCDA IN SELECTION OF DIFFERENT MINING METHODS AND SOLUTIONS
}

\author{
Dejan Stevanović ${ }^{1}$, Milena Lekić1, Daniel Kržanović2 ${ }^{2}$ Ivica Ristović1 \\ ${ }^{1}$ Faculty of Mining and Geology, Djusina 7, 11000 Belgrade, Serbia, e-mail: dejan.stevanovic@rgf.bg.ac.rs; \\ milenalekic@gmail.com; ivica.ristovic@rgf.bg.ac.rs \\ 2 Mining and Metallurgy Institute Bor, Zeleni bulevar 35 19210Bor, Serbia, e-mail:daniel.krzanovic@irmbor.co.rs
}

Received: 2018.01.15

Accepted: 2018.02.01

Published: 2018.03.01

\begin{abstract}
As mine planning is one of the most complicated steps, which depends on a lot of factors as geology, economy etc., consequently, the decision-making process is difficult, due to the existence of a lot of factors for choosing the optimal mining system. In this paper, the method and the result of Analytical Hierarchical Process is presented, shown on a case study - Open pit Drmno, as one of the largest lignite mines in Serbia. The analysis included 6 criteria and two alternatives were applied as Variant 1 and Variant 2. The results show that the suitable mining system for this case study - open pit Drmno is Variant 2.
\end{abstract}

Keywords: mining systems, mining equipment, excavation, analytical hierarchy process.

\section{INTRODUCTION}

The purpose of this paper is to rank mining systems in open pit Drmno as one of the most stable mining system for production of lignite for electricity in power plant in Serbia. For these purposes, selection of relevant parameters was undertaken and calculations were made through the application of multi-criteria analysis (MCA). This method has recently been used in a variety of studies by numerous researchers deliberating different problems. In this paper, analysis includes two different mining systems, Variant 1 and Variant 2 , which will be exposed to analyzis.

The case study is conducted on open pit Drmno. Drmno is a part of Kostolac coal basin, and it operates under governance of Electric Power Industry of Serbia (EPS). Open pit mine "Drmno" is one of the largest and most important lignite mines in Serbia.

Coal deposit Drmno is a part of Kostolac Coal Basin that is covering an area of $164 \mathrm{~km}^{2}$ and it is situated at a distance of $63 \mathrm{~km}$ as a crow fly from Belgrade towards the azimuth of $281^{\circ}$ (Figure 1).
In a micro scale Drmno deposit does not differ from the regional characteristics in the number of plies for main coal III Seam. The III Seam and its two plies are present in $60 \%$ of drill holes, while in the rest of $40 \%$ drill holes layering is present with three up to eight plies (Figure 2) on short distances from $50 \mathrm{~m}$ up to $200 \mathrm{~m}$, spread all around the deposit. Where the III Seam and its plies have micro folding with forming of the dips (narrow-small synclinal), in which the coal elevation drops and then rises along narrow elongated depressions in the floor (Figure 3).

The LCV for Drmno deposit is for III Seam $9.37 \mathrm{MJ} / \mathrm{kg}$ and for II Seam is $7.95 \mathrm{MJ} / \mathrm{kg}$, respectively Ash is $19 \%$ and $24.06 \%$, Moisture $40.41 \%$ and $39.94 \%$. Total grand resources for both III Seam and II Seam are 397,985,544 tons.

The majority of open pit Drmno coal production (over 95\%, Feasibility study [1]) is used for generation of electricity in power plant, as it is usual for large coal open pit mines. This fact is the main reason why coal production capacity of Open pit Drmno, is strongly connected and dependent on power plant objectives. In accordance with, power plant needs, Open pit Drmno 
a)

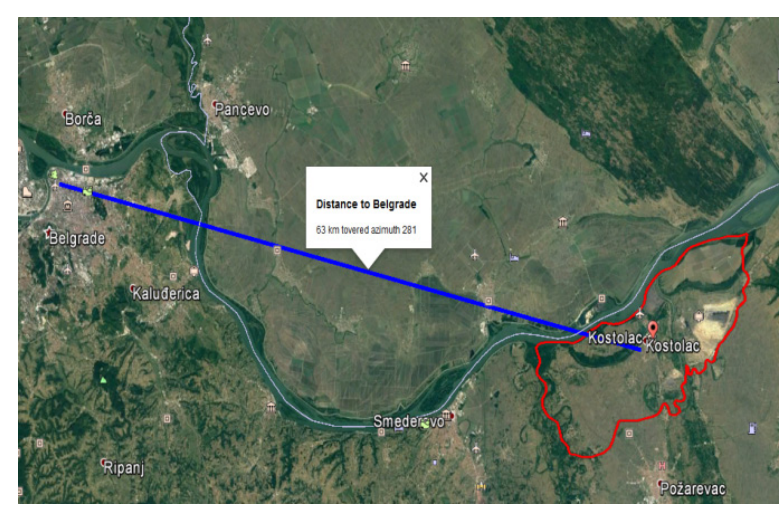

b)

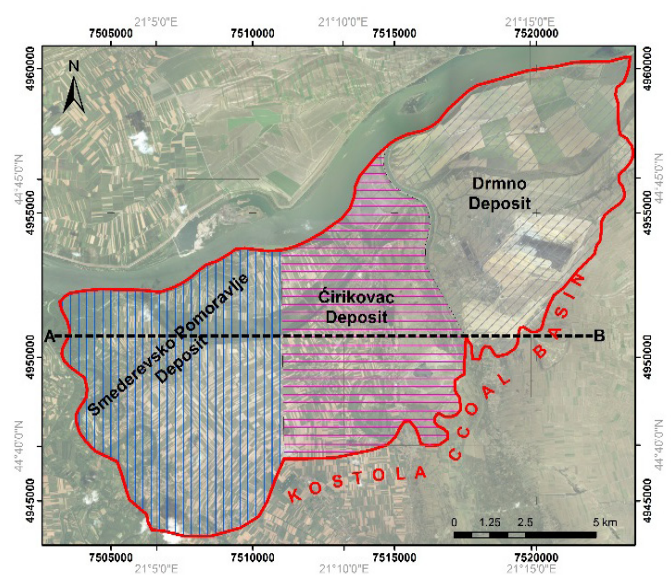

Figure 1. Location map of Kostolac Coal Basin and Drmno Deposit

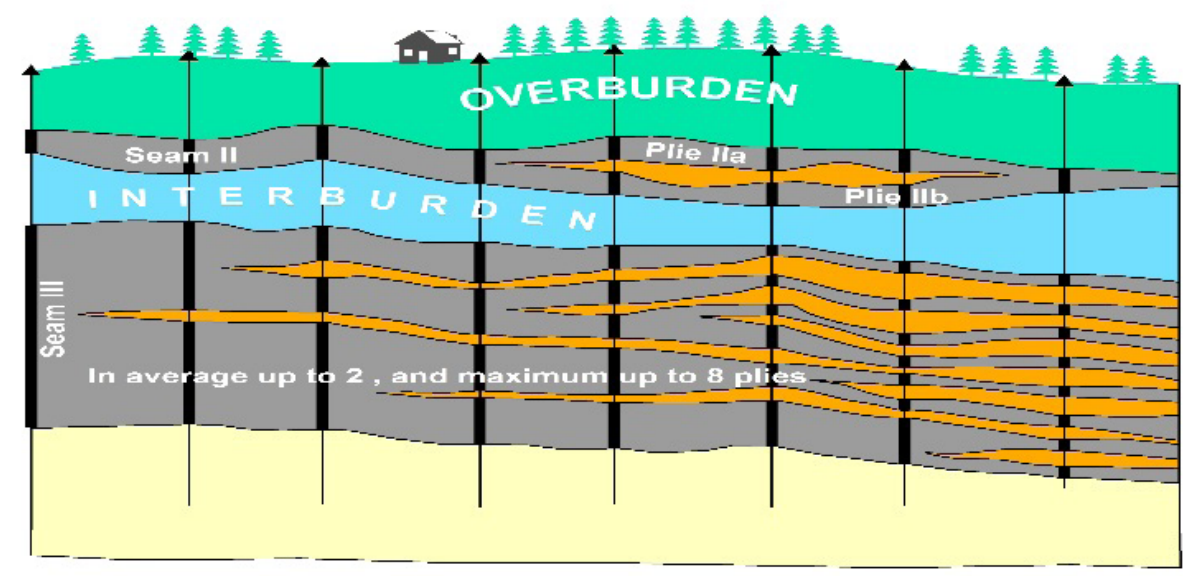

Figure 2. Stratigraphic sequence diagram of Drmno deposit

planed coal production capacity during whole life of mine (LOM) is variable. Currently, $9 \cdot 10^{6} \mathrm{t}$ of coal per year is produced. From year 2019. coal production will significantly increase, to $11.3 \cdot 10^{6}$ $t$ of coal per year. This will be open pits maximum output. During period 2025-2038 coal production will decrease, on $9.5 \cdot 10^{6} \mathrm{t}$ per year. The last ten years of coal exploitation, the capacity will be significantly reduced to $3.5 \mathrm{t}$ per year, marking the end of life of mine (year 2052).

The excavation technology of open pit Drmno, is based on continuous mining equipment. Coal is excavated with 2 ECC systems (Bucketwheel Excavator - Conveyors-Crushing Plant), and 5 ECS systems (Bucket-wheel ExcavatorConveyors-Spreader) are engaged on overburden excavation. Implementation of new (6-th) ECS system is planned for second half of year 2018 .

Currently, only the coal from III Seam is excavated. The average coal thickness is $18 \mathrm{~m}$. The largest quantities of coal are excavated by the II ECC system, which operates along the entire width of the open pit. The remaining amounts of coal are excavated by the I ECC system. The I ECC system, operates only along two-thirds of the open pit width (operates in west and central, not in east part). General scheme of coal excavation systems in open pit Drmno is presented in Figure 4.

\section{CASE STUDY - OPEN PIT DRMNO}

The structure of the deposit, as well as an applied mining method have a significant impact on the complexity of the excavation. In the future this complexity will increase. The basic factors for this kind of development are:

- Increase of the structural complexity of coal in III Seam,

- Planned production enhance (from year 2019),

- Increase of excavation depth and length of the excavation front

- Technological limitations of existing ECC systems 
These factors are the main reason why in some part of III Seam, within the pit limits, existing excavation equipment (bucket-wheel and bucket-chain excavator) will not be able to excavate the entire coal reserve. It is estimated that within pit limits, there is approximately $15 \cdot 10^{6}$ $\mathrm{t}$ of coal (5.3\% of total coal reserves), which is out of reach of existing ECC systems. Calculated value for this coal, estimated at current prices in Serbia $(1.72 € / \mathrm{Gj})$ is around $240 \cdot 10^{6} €$. If not excavated, this coal will soon be covered by the development of internal waste dump, resulting in significant profit loss. Moreover, it could greatly jeopardize inner waste dump slope stability. For these reasons, the abandonment of the mentioned parts of the coal should not be an valid option.

There are 4 typical cases, where coal is out of the reach of the ECC systems (Figure 5).

In two typical cases, coal is out of reach for I ECC system (Case 1 and Case 2, Figure 5). Case 1 usually occurs in central part of open pit, while occurrence of Case 2 is not related to a particular location. Occurrences of Cases 3 and 4, are always related to the east part of open pit. The first and third Cases are caused by the equipment impossibility to operate under a slope of more than $3 \%$, and in Cases 2 and 4, the coal is simply out of equipment reach.

\section{SOLUTION ALTERNATIVES}

As mentioned above, existing excavation equipment (bucket-wheel excavator and bucketchain excavator) is not suitable for coal mining in all parts of deposit. For this reason, it is necessary to define a different mining method for the described parts of the deposit with a complex structure. Two different variants are developed as solution on described problem. Both variants are feasible, and they have been used in coal (lignite) mining practice.

First variant is based on excavation and transport of coal, with dragline excavator. Despite the fact that in mining practice, the dragline excavator is primarily used for digging and transporting of overburden, there are examples of coal (lignite) excavation. Draglines are the lowest cost material removal equipment in common use. Once the characteristics of the deposit alter from the physical limitations of the dragline, the overburden removal becomes costly as the machines' rehandle increases [2].

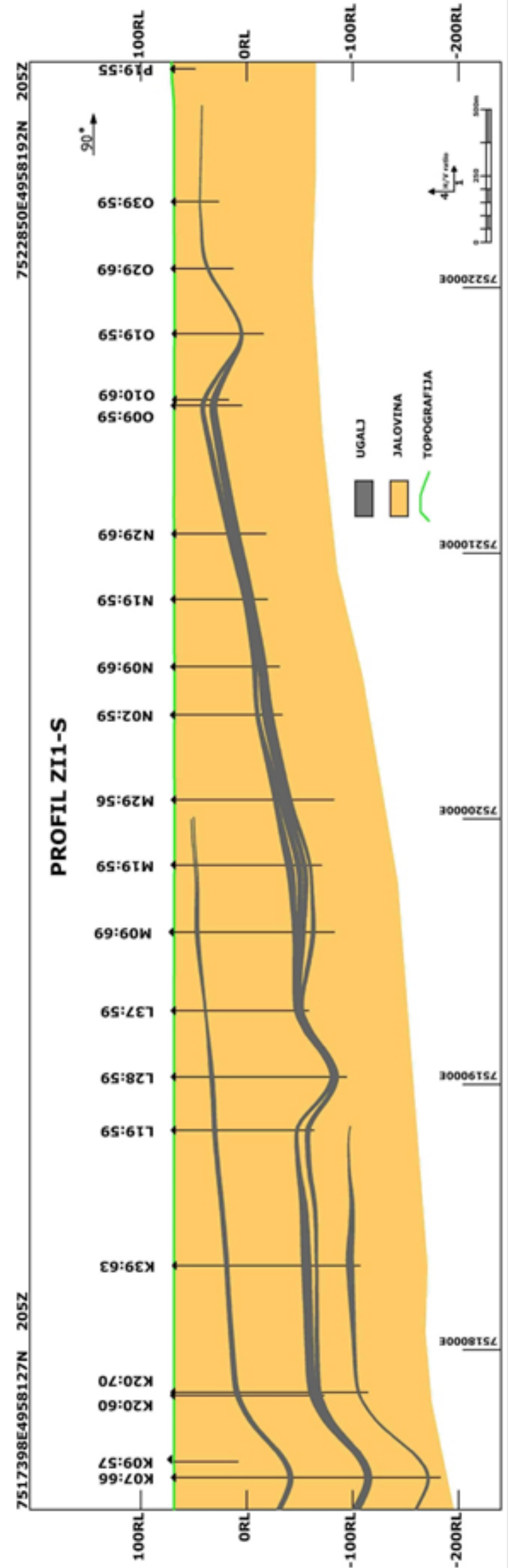

Figure 3. Cross-section trough Drmno deposit 


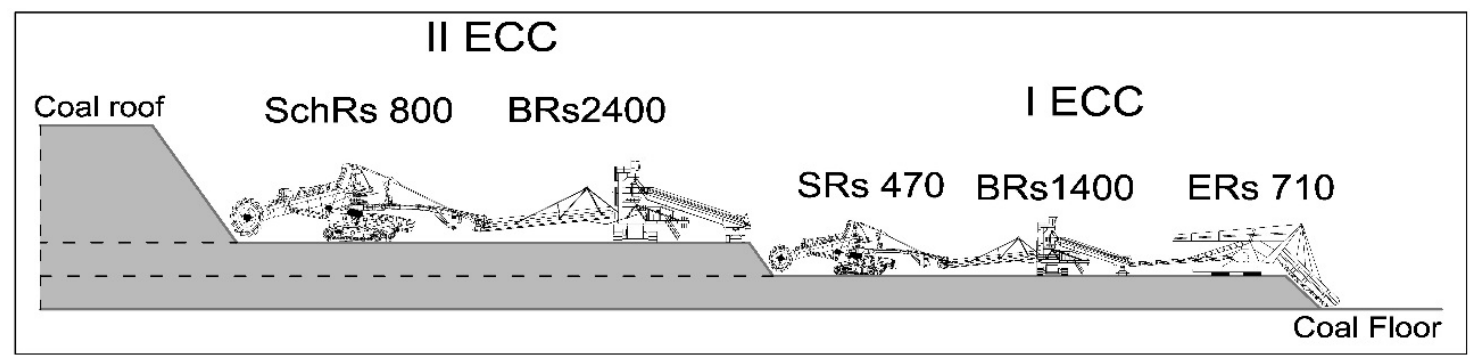

Figure 4. General scheme of coal excavation systems
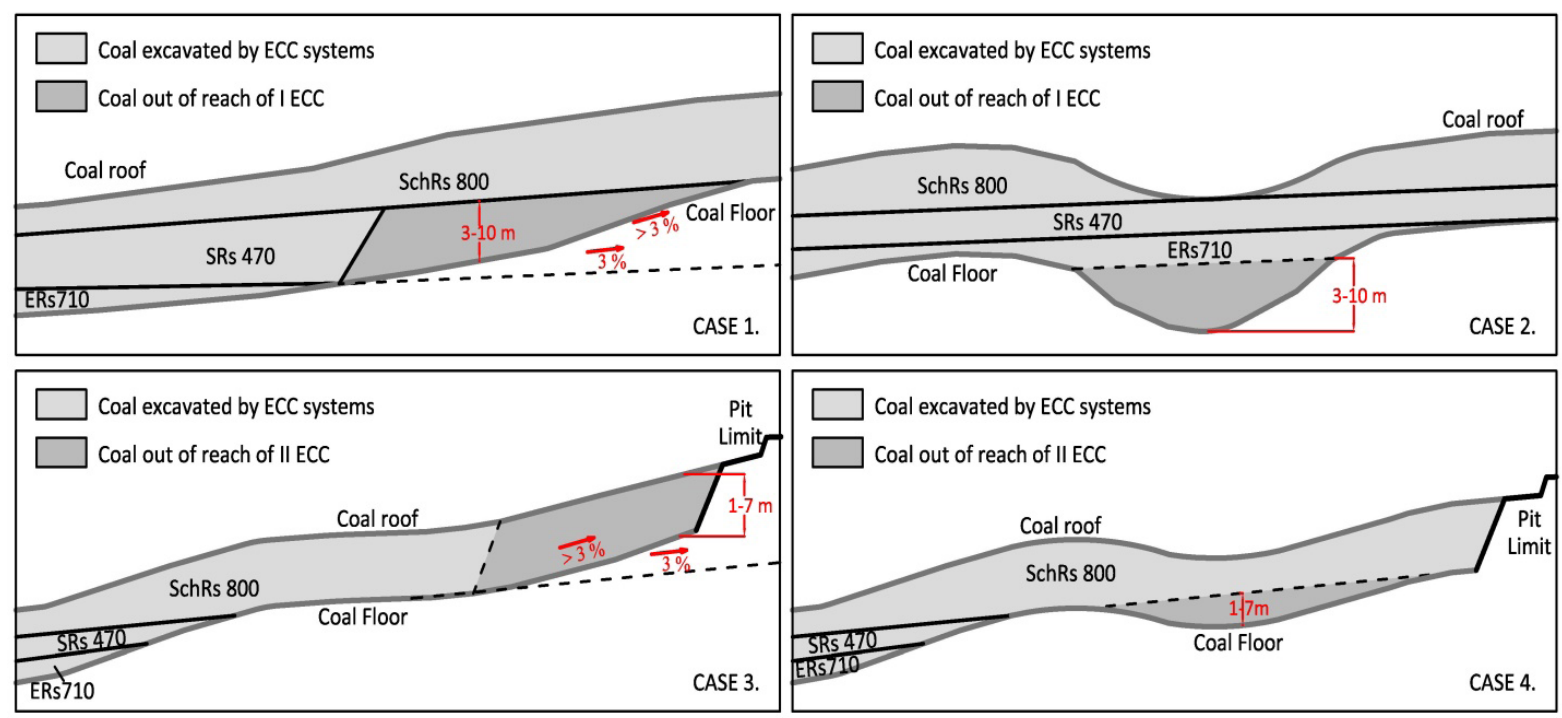

Figure 5. Typical cases - Coal out of reach of the ECC systems

Draglines are generally restricted to: large deposits to ensure adequate strip length and sufficient reserves to justify the capital expenditure, gently dipping deposits, due to spoil instability on steep dips, shallow deposits, as draglines can only excavate a maximum of 50 to $80 \mathrm{~m}$ of material due to reach and dump height limitations [3]. All those restrictions are characteristics of Drmno deposit, and 4 dragline are currently in use on this open pit.

In first variant, coal from problematic part of deposits, is excavated, and unloaded on temporary stockyard, on maximum distance from dragline $(70 \mathrm{~m})$. From this temporary stockyard coal is re-handled by dragline (one or two times) and transported within reach of nearest bucket-wheel or chain -wheel excavator. From this point, handling of coal is done with existing technology. Coal is excavated again with bucket or chainwheel excavator, and transported (by belt conveyors system) to the power plant stockyard. In this variant, excavation and the entire transport of coal to the continuous equipment, is carried out by a dragline. Planned dragline for this operation is Esh $10 / 70$ ad it is already own by open pit Drm- no. This means that, for first variant there is no capital costs. The described first variant scheme is presented in Figure 6.

The second variant is based on excavation and transport of coal, with hydraulic shovel truck system. Shovel and truck mining method is the most flexible mining method and therefore better suited to geological complex deposits, varying overburden depths and thicknesses, and smaller deposits [4]. This characteristic makes the hydraulic excavator a strong alternative for excavation of complex coal part in open pit Drmno. In this variant coal excavation is done with backhoe hydraulic shovel (bucket capacity $4 \mathrm{~m}^{3}$ ). Coal transport is done with fleet of two articulated dump trucks (payload $25 \mathrm{t}$ ).

As in first variant coal is transported on temporally stockyard, within reach of nearest bucketwheel or chain-wheel excavator. From this point, handling of coal is done with existing technology. Coal is excavated again with bucket or chainwheel excavator, and transported (by belt conveyors system) to the power plant stockyard. Second variant scheme, is presented on Figure 7. 


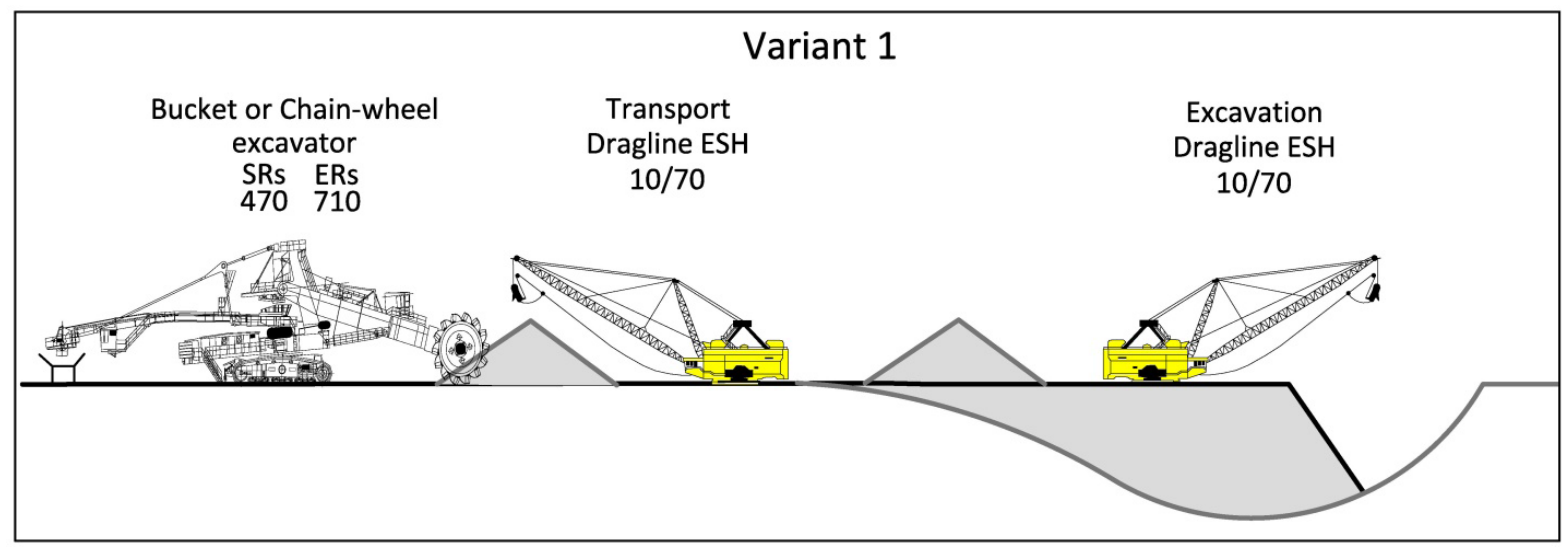

Figure 6. Variant 1 - technology scheme

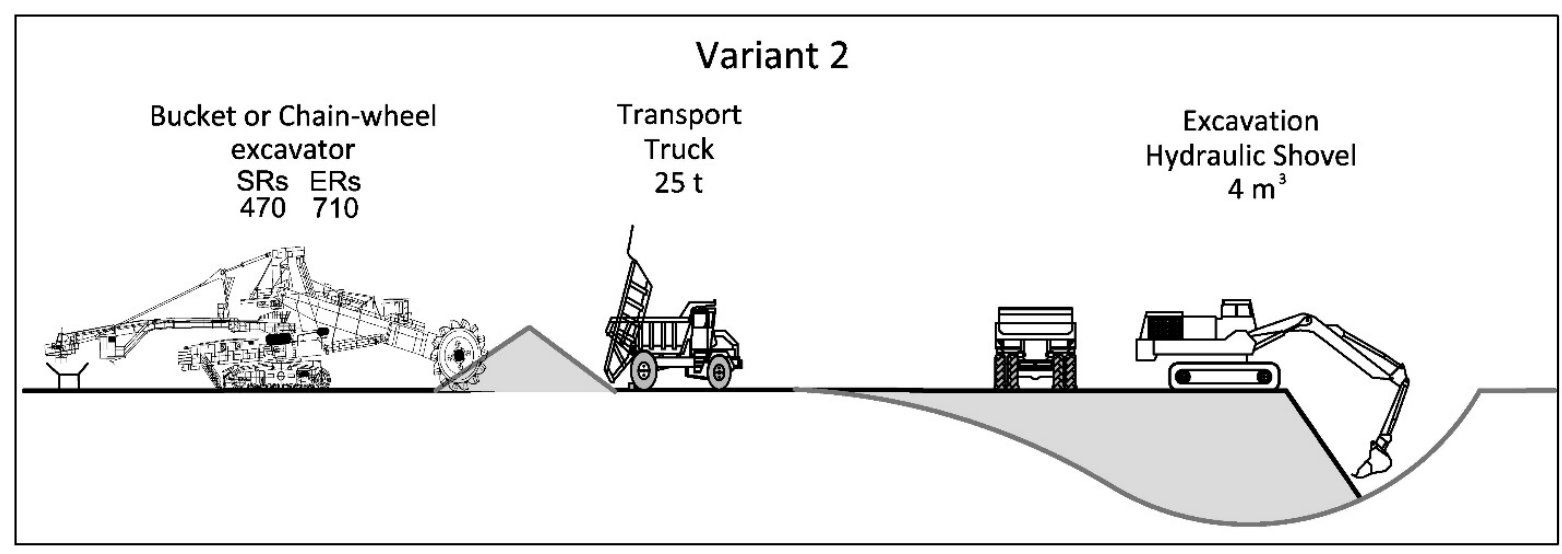

Figure 7. Variant 2 - technology scheme

\section{SELECTION CRITERIA}

The mining equipment selection problem has been studied by many authors $[5,6,7,8,9,10$, $11,12,13]$. In most cases, the leading factors that control the equipment selection process are the same (deposit and working conditions, production performance, capital and operational costs, etc.). However, there are no two different cases, where all factors will be the same or have the same impact. Influential factors for stated problem are listed and briefly described in following text.

Deposit conditions, are leading factors for equipment selection, because they determine feasibility of some solution. Coal outside the reach of continuous mechanization on open pit Drmno, is characterized by structural complexity. Coal seam dips from $3^{\circ}$ to $20^{\circ}$, with changes along the strike on the small distance. Thickness of the coal seam varies from 3 to $20 \mathrm{~m}$, but after continues mechanization excavation, seam thickness is reduced to $1-10 \mathrm{~m}$, which is suitable for equipment from both variants. Due to its flexibility equipment from variant 2 (hydraulic shovel - truck system), is better solution for this complex structural condition.

The complexity of the deposit is not only related to the structure of coal, but also to the appearance of several layers (maximal 8 layers) in the main coal seam. The need for selective excavation and prevention of the coal dilution, significantly favors the hydraulic shovel-truck system.

Physical characteristics of coal also affect the performance of the analyzed equipment. Despite the fact that coal excavation is feasible with equipment from both variants, the hardness of the coal, significantly reduces the productivity of the dragline.

Coal out of reach of continuous mechanization is mainly located along the eastern side of the pit, but is present in significant quantities, along the entire pit. The distance of these locations (often over $2 \mathrm{~km}$ ) emphasizes the importance of equipment mobility. Despite the fact that the mobility of the dragline is much better than mobility of continuous equipment, it is significantly lower than mobility of the hydraulic shovel-truck system. 
Production performance - For both variants calculation shows that planned capacity $\left(0.44 \cdot 10^{6}\right.$ $t$ of coal per year) can be achieved. It is estimated that availability does not favor any variation. With quality maintenance and long service life, dragline availability is relatively constant at value of $80 \%$. The availability of the hydraulic shovel - truck system, is very sensitive to the age of the equipment, and rapidly decreases from about $90 \%$ in the first few years of operation, down to $60 \%$ at the end of the service life (7-9 years of operation). Short lifespan of equipment in the hydraulic shovel - truck system, means that the equipment will be re-purchased, which will return its availability to a high level.

Calculated coal productions for shovel-truck system is $1.1 \cdot 10^{6} \mathrm{t} / \mathrm{year}$, and is practically two time more than required capacity. Dragline calculated production has much lower value, of just $0.6 \cdot 10^{6} \mathrm{t} /$ year. Coal characteristics and need for coal re-handle, significantly reduce the production of dragline. Production performance of both variants are very sensitive to coal transport distance (from excavation location to the reach of continuous mechanization) but in case of dragline excavator, the reduction is significantly higher. It is important to note that the hydraulic shovel - truck system, has a higher capacity reserve which can be used for some other operations on the open pit.

Capital and operational costs - For many authors $[14,15,16,17]$ the concept of optimal equipment selection, implies on system that, in the limits of the work environment, meets the production objectives, while ensuring minimum costs. For the analyzed variants, capital cost are very different. Open pit Drmno already owns dragline Esh 10/70, so the first variant does not have capital costs. In contrast, all equipment from variant 2 is new and must be purchased. Moreover, due to short life, equipment from variant 2 , must be re-punched 3 times. Capital cost for both variants are presented in Table 1.

The estimation of operational costs is based on the data from the open pit, the characteristics of the analyzed mining method and on recommendations from the Mine and equipment estimators guide [17]. Operational cost, for both variants are presented in Table 2.

Significant deference in operational costs is generated by a small length of transport (reduces the cost for hydraulic shovel-truck system) and the need for coal re-handling, which increases the costs in the case of a dragline. Operational costs for the excavation of total coal mass $\left(15 \cdot 10^{6} \mathrm{t}\right)$ are $15.9 \cdot 10^{6} €$ for variant 1 , and $9.6 \cdot 10^{6} €$ for variant 2 . If we add capital to operational costs, the total costs are the same for variant $1\left(15.9 \cdot 10^{6} €\right)$, and for variant 2 the total costs are $14.9 \cdot 10^{6} €$ (or $0.992 € / \mathrm{t}$ ). According to the cost criterion, variant 2 is better by $1 \cdot 10^{6} €$ or by approximately $7 \%$.

Working area conditions - The production performance can be significantly affected by the conditions of the workspace. Coal excavation area is characterized by: small sizes and proximity to continuous mining systems. For this reason, planned excavation has to be coordinated with the development and progress of continuous systems. In these conditions, the advantage is given to Variant 2 (despite its greater complexity) because it has much better flexibility and mobility.

Table 1. Capital cost for both variants

\begin{tabular}{|c|c|c|c|}
\hline Variant 1 & \multicolumn{3}{|c|}{ Variant 2} \\
\hline \multirow{3}{*}{$0 €$} & Hydraulic Shovel & Two Trucks & Total \\
\hline & $950.000 €$ & $2 \times 400.000=800.000 €$ & $1.750 .000 €$ \\
\hline & $\begin{array}{c}\text { Three re-purchases } \\
3 \times 950.000=2.850 .000 €\end{array}$ & $\begin{array}{c}\text { Three re-purchases } \\
3 \times 800.000=2.400 .000 €\end{array}$ & $5.250 .000 €$ \\
\hline
\end{tabular}

Table 2. Operational cost for both variants

\begin{tabular}{|c|c|c|c|c|c|c|c|}
\hline Normative & $\begin{array}{c}\text { Maintenance } \\
\text { Parts }(€ / t)\end{array}$ & $\begin{array}{c}\text { Labor } \\
(€ / t)\end{array}$ & $\begin{array}{c}\text { Power } \\
(€ / t)\end{array}$ & $\begin{array}{l}\text { Lube } \\
(€ / \mathrm{t})\end{array}$ & $\begin{array}{c}\text { Tires } \\
(€ / t)\end{array}$ & $\begin{array}{c}\text { Wear Parts } \\
(€ / t)\end{array}$ & $\begin{array}{l}\text { Total } \\
(€ / t)\end{array}$ \\
\hline \multicolumn{8}{|c|}{ Variant 1} \\
\hline Dragline & 0.186 & 0.205 & 0.398 & 0.149 & 0 & 0.118 & 1.06 \\
\hline \multicolumn{8}{|c|}{ Variant 2} \\
\hline Hydraulic shovel & 0.065 & 0.055 & 0.1605 & 0.0365 & 0 & 0.0244 & 0.341 \\
\hline Truck & 0.025 & 0.037 & 0.136 & 0.038 & 0.037 & 0.028 & 0.301 \\
\hline Total: Hydraulic Shovel - Truck System & 0.090 & 0.091 & 0.297 & 0.074 & 0.037 & 0.052 & 0.641 \\
\hline
\end{tabular}


Organizational complexity and implementation - for Variant 1, equipment (dragline excavator) is already owned by open pit. Also, the workforce for the operation and maintenance of dragline excavator already exists. This means that the implementation of Variant 1 is organizationally simple, not time consuming and it comes down to the positioning of the dragline excavator on the desired location.

In this case, Variant 2 has significantly worse performance. All equipment must be purchased and workers must be trained to operate and maintain it. It is difficult to estimate, but minimum one year is needed for the equipment delivery and workers trainings.

Auxiliary equipment - Equipment from both variants constantly works in the coal seam, with a maximum operational gradient of 3\% (formed by continuous equipment) so special preparation of workspace and road construction are not necessary. Existing road infrastructure is suitable for pit exiting. Bulldozers which are already operating along continuous mining systems will be sufficient, regardless of the adopted variant.

\section{METHODOLOGY OF ANALYTICAL HIERARCHICAL PROCESS}

The Analytical Hierarchical Process (AHP) method is one of the most frequently used and an effective tool in Multi-Criteria-Analysis for dealing with problems of decision making, introduced by Thomas Saaty [18].

In the papers of Saaty $[19,20,21]$ the axios for establishing AHP were defined. In the literature, AHP, has been widely used in solving many complicated decision-making problems. Recently, [22] used the AHP for the selection in mining. Bital Samanta et. al. [23], Kazagidis et al. [24] applied the AHP to improve management in mining. Dağdeviren [25], Milisavljević et. al. [26], also used this method to analyze decision making in eqipment selection. Milentijević et al. [27] presented the use of MCA method in mining from environmental aspects.

AHP is applied for analysis of the decisionmaking process and solving complex multicriteria problems, utilizing elements of goal, criteria, sub-criteria and alternatives. The most common application of the AHP method is a result of its ability to identify and analyze inconsistency of the decision makers in the process of validating the hierarchical elements.

AHP is based on opinion of experts, therefore, it can be said that this method is a subjective one. The most common application of the AHP method is a result of its ability to identify and analyze inconsistency of the decision makers in the process of validating the hierarchical elements (Figure 8). The variability of this method can be seen in the ability to measure mistakes in the decision-making process, by calculation of the consistency rate.

The AHP breaks down the complex problems into hierarchy and mutual comparison of their elements. The goal of inquiry is placed at the top of the hierarchy and is not compared with any other elements. On the first level, the criteria are mutually compared in pairs in relation with the first upper level of the hierarchy Table 5. On the last level of hierarchy, the alternatives are compared in relation to each criterion separately. Every comparison of two elements of the hierarchy (model) is done by using Saaty's scale (Table 3), expressed by equation 1 .

$$
S=\left\{\frac{1}{9}, \frac{1}{8}, \frac{1}{7}, \frac{1}{6}, \frac{1}{5}, \frac{1}{4}, \frac{1}{3}, \frac{1}{2}, 1,2,3,4,5,6,7,8,9\right\}
$$

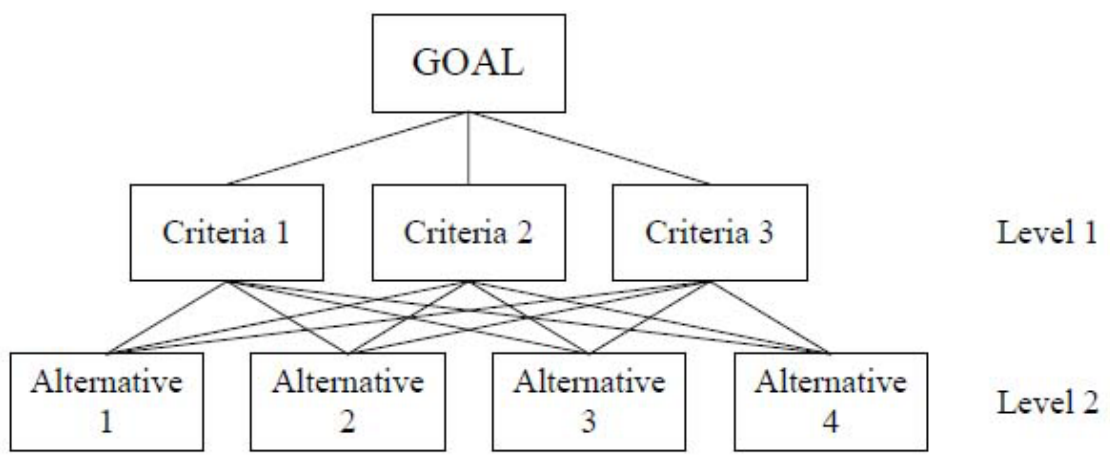

Figure 8. Scheme of hierarchy levels of AHP 
Table 3. The Saaty scale

\begin{tabular}{|c|l|l|}
\hline No & \multicolumn{1}{|c|}{$\begin{array}{c}\text { Value of the } \\
\text { Category }\end{array}$} & Description \\
\hline 1 & Same value & Two elements are the same \\
\hline 2 & Inter value & $\begin{array}{l}\text { Compromise needed, or further } \\
\text { division }\end{array}$ \\
\hline 3 & Week dominance & $\begin{array}{l}\text { Experience or judgment are in } \\
\text { slight favor of one }\end{array}$ \\
\hline 4 & Inter value & $\begin{array}{l}\text { Compromise needed, or further } \\
\text { division }\end{array}$ \\
\hline 5 & Strong dominance & $\begin{array}{l}\text { Experience or judgment are in } \\
\text { significant favor of one element } \\
\text { compared to other }\end{array}$ \\
\hline 7 & Inter value & $\begin{array}{l}\text { Compromise needed, or further } \\
\text { division }\end{array}$ \\
\hline 8 & Inter value & $\begin{array}{l}\text { Dominance of one value } \\
\text { confirmed in practice }\end{array}$ \\
\hline 9 & $\begin{array}{l}\text { Absolute } \\
\text { dominance }\end{array}$ & $\begin{array}{l}\text { Compromise needed, or further } \\
\text { division }\end{array}$ \\
\hline
\end{tabular}

The basic results of the AHP method are weight criterion rate $(\mathrm{W})$. The weight coefficients are calculated for each element at a certain level. The techniques for the weight coefficient vectors W recommended by Saaty include summarizing the comparison results matrix rows and normalization of the obtained sums, according to the Equation (2):

$$
\sum_{j=1}^{n} \frac{W_{i}}{W_{j}}=W_{i}\left(\sum_{j=1}^{n} \frac{1}{W_{j}}\right) i=1, \ldots, n
$$

The errors in the process of adding values to the elements in coupling comparison are determined by consistency rate (CR) calculation. In order to calculate the CR, the consistency index $(\mathrm{CI})$ should be calculated according to Equation (3):

$$
C I=\frac{\lambda_{\max }-n}{n-1}
$$

where: $\lambda_{\max }$ is maximum value of the evaluation matrix.

The closer $\lambda_{\max }$ is to the number of alternatives $(n)$, the less inconsistency there is. $\lambda \max$ is calculated by Equation (4):

$$
\lambda_{\max }=\frac{1}{n} \sum_{i=1}^{n} \lambda_{i}
$$

By putting $\lambda$ max from Equation (3) in Equation (4), the CI is determined. Consistency rate (CR) is the ratio of the consistency index (CI) and random index (RI), according to Equation (5):

$$
C R=\frac{C I}{R I}
$$

Random index (RI) depends on the matrix row, and is taken from Table 6 , in which the first row is compared to the matrix row, and the second row is composed of RI.

If the consistency rate (CR) is less than 0.1 $(10 \%)$, the result is consistent and there is no need for changes and calculation repetition. If the consistency rate is higher than 0.1 , the result is considered inconsistent and a partial or complete correction of results, by repeating the double comparison and achieving a satisfactory consistency rate, is needed.

\section{RESULTS AND DISCUSSION}

In Table 4, the analyzed criteria which were used as input data for matrix formatting and quantification for coupled comparison of criteria according to the Saaty scale are presented (Table 5). Those data are then included into the calculations by AHP method, through all steps in calculation process of this method.

Matrix with double comparison is formed by AHP method based on previously set criteria. Weight coefficients for each criteria are calculated by mutual comparison and based on Saaty's scale (Table 3). Criteria are added values by direct and inverted procedure in span from 1 to 9 .

By valuing each criterion, weight coefficient of criteria was gained. The values are shown in Table 6. For the purpose of control of the obtained results, calculations of the $C R$ are done. Results obtained confirmed that decision is consistent because its value is less than 0.1 , or its value is 0.0103 (Table 7). Based on results of the calculation done by AHP method, final alternative rank was given in Table 8 .

The consistency rate $(C R)$ for all criteria is 0.00 because we have two alternatives (Variant 1 and Variant 2) and in that case we do not need to calculate the value [28]. Final result of ranking alternatives (Variant 1 and Variant 2), obtained by Analytical Hierarchical Process gives Variant 2 $(0.4050)$ as a better alternative (solution) in this case of study - open pit Drmno. 
Table 4. Values of Random Index (RI) [18]

\begin{tabular}{|c|c|c|c|c|c|c|c|c|c|c|c|c|c|c|c|}
\hline$n$ & 1 & 2 & 3 & 4 & 5 & 6 & 7 & 8 & 9 & 10 & 11 & 12 & 13 & 14 & 15 \\
\hline $\mathrm{RI}$ & 0.0 & 0.0 & 0.58 & 0.9 & 1.12 & 1.24 & 1.32 & 1.41 & 1.45 & 1.49 & 1.51 & 1.48 & 1.56 & 1.57 & 1.59 \\
\hline
\end{tabular}

Table 5. Double comparison matrix of the criteria according to the Saaty scale

\begin{tabular}{|l|c|c|c|c|c|c|}
\hline \multicolumn{1}{|c|}{ GOAL } & $\begin{array}{l}\text { Deposit } \\
\text { Conditions }\end{array}$ & $\begin{array}{l}\text { Production } \\
\text { performance }\end{array}$ & $\begin{array}{c}\text { Capital and } \\
\text { operational } \\
\text { cost }\end{array}$ & $\begin{array}{c}\text { Working area } \\
\text { conditions }\end{array}$ & $\begin{array}{c}\text { Organizational } \\
\text { complexity and } \\
\text { implementation }\end{array}$ & $\begin{array}{c}\text { Auxiliary } \\
\text { equipment } \\
\text { need }\end{array}$ \\
\hline Deposit Conditions & 1 & 2 & 3 & 4 & 4 & 4 \\
\hline Production performance & $1 / 2$ & 1 & 2 & 3 & 3 & 3 \\
\hline Capital and operational cost & $1 / 3$ & $1 / 2$ & 1 & 2 & 1 & 1 \\
\hline Working area conditions & $1 / 4$ & $1 / 3$ & $1 / 2$ & 1 & 1 & 1 \\
\hline $\begin{array}{l}\text { Organizational complexity } \\
\text { and implementation }\end{array}$ & $1 / 4$ & $1 / 3$ & 1 & 1 & 1 & 1 \\
\hline Auxiliary equipment need & $1 / 4$ & $1 / 3$ & 1 & 1 & 1 & 1 \\
\hline
\end{tabular}

Table 6. Weight coefficient criteria and their level of consistency

\begin{tabular}{|l|c|}
\hline Criteria & Weight Coefficient \\
\hline Deposit Conditions & 0.3742 \\
\hline Production performance & 0.2411 \\
\hline Capital and operational cost & 0.1177 \\
\hline Working area conditions & 0.0825 \\
\hline $\begin{array}{l}\text { Organizational complexity and } \\
\text { implementation }\end{array}$ & 0.0923 \\
\hline Auxiliary equipment need & 0.0923 \\
\hline
\end{tabular}

Table 7. Value of maximum value of the evaluation matrix ( $(\max )$, Consistency index $(C I)$, Random index $(R I)$ and Consistency level $(C R)$

\begin{tabular}{|c|c|}
\hline$\wedge \max$ & 6.0638 \\
\hline $\mathrm{Cl}$ & 0.0127 \\
\hline $\mathrm{RI}$ & 1.24 \\
\hline$C R$ & 0.0103 \\
\hline
\end{tabular}

Table 8. Final alternative rank

\begin{tabular}{|c|c|c|}
\hline & & RANK \\
\hline Variant 1 & 0.4050 & 2 \\
\hline Variant 2 & 0.5950 & 1 \\
\hline
\end{tabular}

\section{CONCLUSION}

The success of open pit production depends on a large number of more or less influential factors. General and global optimization, based on all of these factors is not possible, and an optimal compromise is the solution. In this respect, it is extremely important to select a hierarchy (i.e. a method for defining a hierarchy) that determines the importance of each factor. Establishing such a hierarchy is a complex process which is authentic for each particular mining system. In this case, according to AHP method, we can conclude that the second variant (Variant 2) is better solution for this case study - Open-pit Drmno.

It is practically impossible to define the mining system and equipment within it, which will fully correspond to all given factors. Still, selected mining system must be an optimal solution for the leading factors, while in the case of other factors, the equipment usually cannot fully meet all the conditions, i.e. it is accepted as a suboptimal solution.

\section{Acknowledgments}

Research described in this paper was performed during development of the technical development project TR33025 and TR33039. Development of this projects is financed by Ministry of Science and Technological Development, Republic of Serbia.

\section{REFERENCES}

1. Feasibility study with a project of providing the required quantities of coal for the operation of the existing power plants in the "TE-KO" Kostolac and the new block B3 (350MW), Faculty of Mining and Geology, Belgrade, 2013

2. Scott B., Ranjith P.G., Choi K. and Khandelwa, $\mathrm{M}$. A review on existing opencast mining methods within Australia, Journal of Mining Science 46, 2010, 280-297. 
3. Wescott P. The Inaugural UNSW/ Mitsubishi Lecture: Dragline or Truck and Shovel? -Some technical and business considerations. Presented to the School of Mining Engineering, University of New South Wales, May 2004.

4. Westcott P., Pitkin G. and Aspinall T. Open-cut mining. In: Australasian Coal Mining Practice, Chapter 18, Monograph 12, Third Edition, Eds. Kininmonth, R.J and Baafi, E.Y. 2009, 410-458, AusIMM, Melbourne, Victoria, Australia

5. Samanta B., Sarkar B. and Mukherjee S.K. Selection of Opencast Mining Equipment by Multi-Criteria Decision-Making Process, Mining Technology, Maney Publishing, 111, 2002, 136-142.

6. Basçetin A. Decision support system for optimal equipment selection in open pit mining: analytical hierarchy process, Istanbul University. Müh. Fak. Yerbilimleri Dergisi, 16, 2003, 1-11.

7. Bazzazi A.A., Osanloo M. and Karimi B. A new fuzzy multi criteria decision making model for open pit mines equipment selection, 2011, AsiaPacific Journal of Operational Research, 28, 2011, 279-300.

8. Christina B. and Caccetta L. Equipment Selection for Surface Mining: A Review- Draft paper, Department of Mathematics and Statistics, University of Melbourne, Melbourne, Australia, Department of Mathematics and Statistics, Curtin University of Technology, Bentley, Australia, 2013.

9. Fedorko G., Molnar V., Dovica M., Toth T. and Kopas M. Analysis of pipe conveyor belt damaged by thermal wear, Eng. Fail. Anal., 45, 2014, 41-48.

10. Fedorko G., Molnar V., Grincova A., Dovica M., Toth T., Husakova N., Taraba V. and Kelemen M. Failure analysis of irreversible changes in the construction of rubber-textile conveyor belt damaged by sharp-edge material impact, Eng. Fail. Anal., 39, 2014, 135-148.

11. Molnar V., Fedorko G.; Stehlikova B. and Paulikova A. Influence of tension force asymmetry on distribution of contact forces among the conveyor belt and idler rolls in pipe conveyor during transport of particulate solids, Measurement, 63, 2015, 120-127.

12. Klepka T., Debski H. and Rydarowski H.Characteristics of high-density polyethylene and its properties simulation with use of finite element method, Polimery, 54, 2009, 668-672.

13. Jachowicz T. and Sikora R. Methods of forecasting of the changes of polymeric products properties, Polimery, 51, 2006, 177-185.

14. Lizotte. Y. Economic and Technical Relations Between Open Pit Design and Equipment Selection, Mine Planning and Equipment Selection. Singhal (Ed.). Balkema. Rotterdam, 1988.
15. Sharma N.K., An Alternative Approach to Procurement of Equipment: Coal India's Experience, International Conference on the Management of Mining Machinery, MGMI, Calcutta, India, 8-9 July, 1999.

16. Bozorgebrahimi E., Hall R. A. and Blackwell G. H. Sizing equipment for open pit mining - a review of critical parameters, Min. Tech. (Trans. Inst. Min. Metall), 112, 2003, A171-A179.

17. Aykul H., Yalcın E., Ediz I.G., Dixon-Hardy D.W. and Akcakoca H. Equipment selection for high selective excavation surface coal mining, The Journal of The Southern African Institute of Mining and Metallurgy, 107, 2007, 195-210.

18. Saaty T. The Analytical Hierarchy Process; McGraw-Hill: New York, NY, USA., 1980.

19. Saaty T. Axiomatic foundation of the analytic hierarchy process. Manag. Sci., 32, 1986, 841-855.

20. Alphonce C.B. Application of the Analytic Hierarchy Process in Agriculture in Developing Countries. Agric. Syst., 53, 1997, 97-112.

21. Harker P.T. and Vargas, L.G. The theory of ratio scale estimation: Saaty's Analytic hierarchy process. Manag. Sci., 33, 1987, 1383-1403.

22. Ataei M., Jamshidi M., Sereshki F. and Jalali, S.M.E. Mining method selection by AHP approach, Journal of the Southern African Institute of Mining and Metallurgy, 108, 2008, 741-749.

23. Bimal S., Sarkar B. and Mukherjee S. K. Selection of opencast mining equipment by a multi-criteria decision-making process, Mining Technology, Transactions of the Institutions of Mining and Metallurgy: Section A, Technical notes, 111, 2013,

24. Dağdeviren M., Decision making in equipment selection: an integrated approach with AHP and PROMETHEE, Journal of Intelligent Manufacturing, 19, 2008, 397-406.

25. Kazakidis V.N., Mayer Z. and Scoble M.J. Decision making using the analytic hierarchy process in mining engineering, Mining Technology, Transactions of the Institutions of Mining and Metallurgy: Section A, 113, 2013, 30-42.

26. Milentijević G., Nedeljković B., Lekić M., Nikić Z., Ristović I. and Djokić J. Application of a Method for Intelligent Multi-Criteria Analysis of the Environmental Impact of Tailing Ponds in Northern Kosovo and Metohija, Energies, 9, 2016, 935-951.

27. Milisavljević V., Medenica D., Čokorilo V. and Ristović I. New approach to equipment quality evaluation method with distinct functions, 20, 2016, 743-752.

28. Mu E. and Pereyra-Rojas M. Practical Decision Making, Chapter 2, Understanding the Analytic Hierarchy Process, SpringerBriefs in Operations Research, 2017. 